\begin{tabular}{|c|c|}
\hline Title & 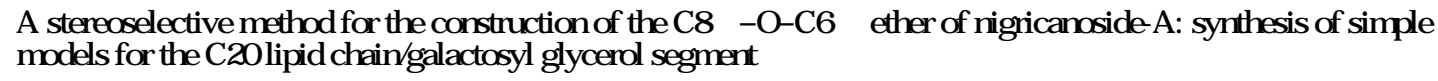 \\
\hline Author(s) & Kinashi, Naoto; Fujiwara, Kenshu; T sunoda, Takayuki; Katoono, Ryo; Kawai, Hidetoshi; Suzuki, Takanori \\
\hline Citation & $\begin{array}{l}\text { Tetrahedron Letters, } 54(34), 4564.4567 \\
\text { https:/doi.org/10.1016/.tetlet.2013.06.085 }\end{array}$ \\
\hline Issue Date & $2013-08-21$ \\
\hline Doc URL & http:/hdl .handle.net/2115/58265 \\
\hline Type & article (author version) \\
\hline File Information & TL_54_p4567-.pdf \\
\hline
\end{tabular}

Instructions for use 


\section{Graphical Abstract}

To create your abstract, type over the instructions in the template box below.

Fonts or abstract dimensions should not be changed or altered.

A stereoselective method for the construction of the C8'-

O-C6" ether of nigricanoside-A: Synthesis of simple

Leave this area blank for abstract info.

models for the C20 lipid chain/galactosyl glycerol segment

Naoto Kinashi, Kenshu Fujiwara, * Takayuki Tsunoda, Ryo Katoono, Hidetoshi Kawai, Takanori Suzuki

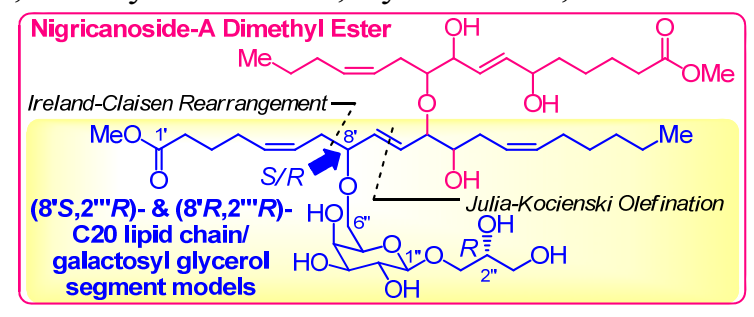


Tetrahedron Letters

journal homepage: www.elsevier.com

\title{
A stereoselective method for the construction of the C8'-O-C6" ether of nigricanoside- A: Synthesis of simple models for the C20 lipid chain/galactosyl glycerol segment
}

\author{
Naoto Kinashi, Kenshu Fujiwara,* Takayuki Tsunoda, Ryo Katoono, Hidetoshi Kawai, ${ }^{\dagger}$ Takanori Suzuki \\ Department of Chemistry, Faculty of Science, Hokkaido University, Sapporo 060-0810, Japan
}

\section{ARTICLE INFO}

Article history:

Received

Received in revised form

Accepted

Available online

Keywords:

Natural product synthesis

Monogalactosyl diacyl glycerol

Ireland-Claisen rearrangement

Ether lipid

Stereoselective synthesis

\section{ABSTRACT}

A method for the stereoselective construction of the C8'-O-C6" ether of nigricanoside-A, an antimitotic natural product from the green alga Avrainvillea nigricans, has been developed based on chirality-transferring Ireland-Claisen rearrangement. The method was successfully applied to the synthesis of simple models for the C20 lipid chain/galactosyl glycerol segment of the natural product.

2013 Elsevier Ltd. All rights reserved.
Nigricanoside-A (1) (Fig. 1), isolated as a strong antimitotic agent $\left[\mathrm{IC}_{50}\right.$ of nigricanoside-A dimethyl ester (2): $3 \mathrm{nM}$ against human breast cancer MCF-7 cells] from the green alga Avrainvillea nigricans by Andersen, ${ }^{1}$ is a unique oxylipin derivative including two oxygenated fatty acids and a galactosyl glycerol moiety that are connected to each other by ether bonds. ${ }^{2}$ Although the planar structure and the partial relative stereochemistry of $\mathbf{1}$ have been elucidated by intensive NMR analysis of the dimethyl ester (2) of $\mathbf{1}$, full assignment of the relative and absolute stereochemistries of $\mathbf{1}$ has yet to be completed. The unique structure and the strong bioactivity of $\mathbf{1}$ have prompted us to attempt its total synthesis and full stereochemical assignment. At the beginning of the project, we developed an effective method for the stereoselective construction of the C8'-O-C6" ether bond of 1 connecting the galactose moiety to the $\mathrm{C} 20$ fatty acid chain based on chirality transferring Ireland-Claisen rearrangement. ${ }^{3}$ Here, the details of the development and application of the method to the synthesis of simple models [(8'S,2' $R)-3$ and $\left.\left(\mathbf{8}^{\prime} \boldsymbol{R}, \mathbf{2}^{\prime} ' \boldsymbol{R}\right)-3\right]$ for the C20 lipid chain/galactosyl glycerol segment of $\mathbf{1}$ are described.

Model compounds (8'S,2'"R)-3 and (8'R,2'"'R)-3, excluding the $\mathrm{C} 16$ fatty acid chain and the oxygen functionalities at $\mathrm{C} 11^{\prime}$ and $\mathrm{C} 12$ ', were designed for the following purpose: (i) a simple demonstration of the stereoselective construction of the C8'-OC6" ether of 1, (ii) comparison of the NMR spectra with 2 to predict the configuration at C8' of $\mathbf{1}$, and (iii) investigation of the structure-activity relationship in antimitotic/cytotoxic assays of $\mathbf{1}$. The (2"'R)-configuration of the models was designed according to the proposed $(R)$-configuration at $\mathrm{C} 2$ "' of the glycerol of $\mathbf{1}$, which was based on the assumption that nigricanosides were oxidative metabolites of monogalactosyl diacyl glycerols (MGDGs), known as chloroplast membrane lipids, having a common 3-galactosyl-sn-glycerol structure. ${ }^{4}$ In this preliminary report, we disclose the synthesis and NMR analysis of the models. ${ }^{5}$

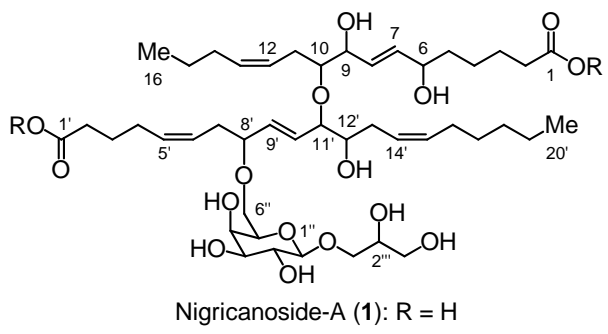

Nigricanoside-A Dimethyl Ester (2): $\mathrm{R}=\mathrm{Me}$

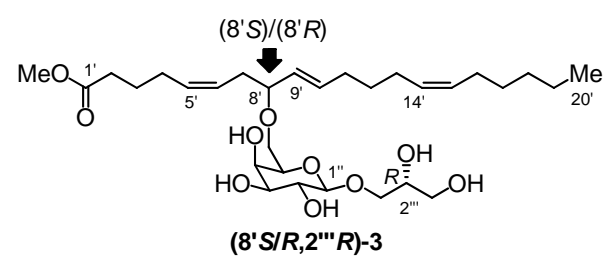

Figure 1.

\footnotetext{
* Corresponding author. e-mail: fjwkn@sci.hokudai.ac.jp

${ }^{\dagger}$ Present address: Department of Chemistry, Faculty of Science, Tokyo University of Science, Shinjuku-ku, Tokyo 162-8601.
} 
Tetrahedron Letters

The synthetic plan for the model compounds (3) is outlined in Scheme 1. The Z-olefin groups at C5' and C14' of 3 were scheduled to be formed by Lindlar hydrogenation of the corresponding alkyne groups at the final stage of the synthesis after aldehyde $\mathbf{4}$ and sulfone $\mathbf{5}$ were connected by JuliaKocienski olefination ${ }^{6}$ to form the E-olefin at C9'. The Zbromoalkene at $\mathrm{C}^{\prime}$ ' of 4 would be converted to an alkyne group under mild basic conditions after the olefination step. For the construction of the $\mathrm{C} 8$ ' stereocenter and the Z-bromoalkene of 4, the Ireland-Claisen rearrangement of ester $\mathbf{6}$ was employed. The rearrangement was expected to exhibit perfect chirality transfer from $\mathrm{C}^{\prime}$ of 6 to $\mathrm{C}^{\prime}$ of $\mathbf{4}$. Therefore, bromoalkenol $\mathbf{8}$, which would be condensed with glycolic acid derivative $\mathbf{7}$ to form $\mathbf{6}$, must be obtained in enantiomerically pure form. Thus, both enantiomers (S)-8 and (R)-8 would be prepared by chiral resolution.

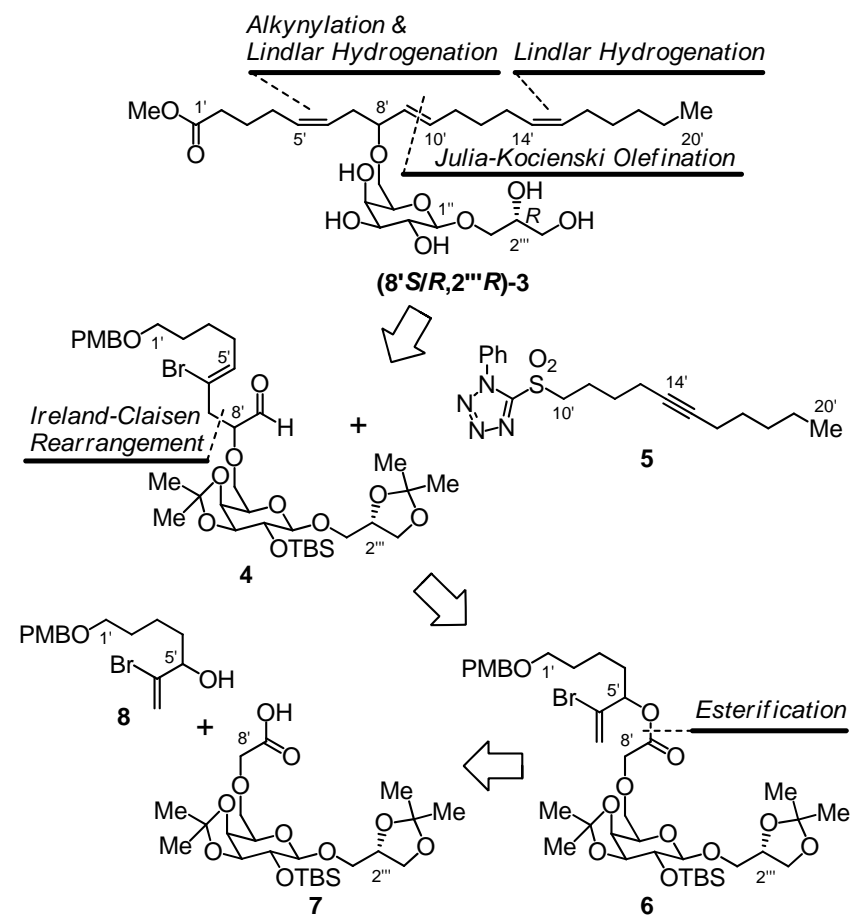

Scheme 1. Synthetic plan for model 3.
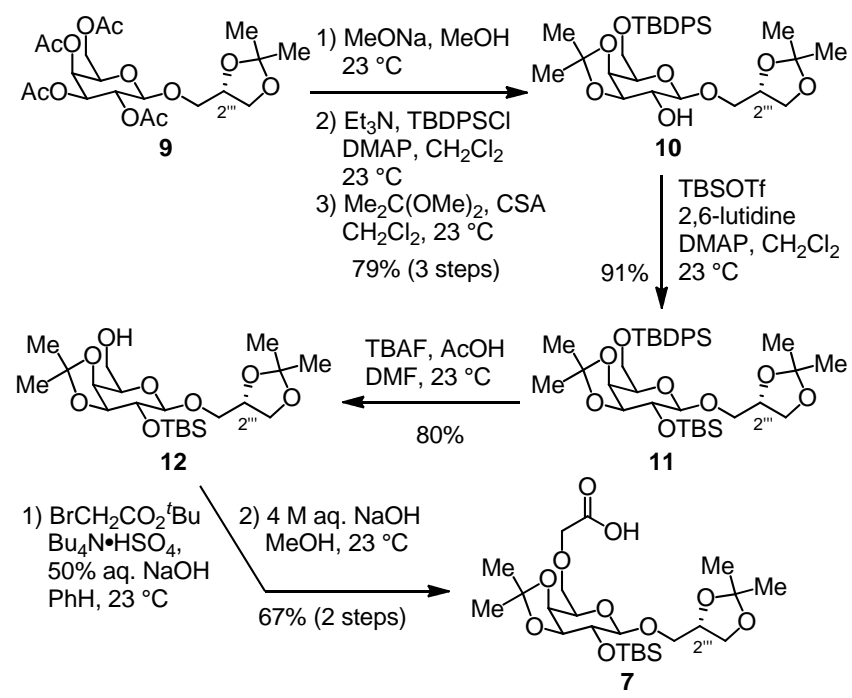

Scheme 2. Synthesis of carboxylic acid 7.

The synthesis of glycolic acid 7 from the known 3-galactosylsn-glycerol derivative $\mathbf{9}^{7}$ is shown in Scheme 2. The acetate groups of 9 were removed by methanolysis, and the resulting tetraol was subjected to stepwise protection with TBDPSCl and 2,2-dimethoxypropane to give alcohol 10 (79\% over 3 steps). The protection of $\mathbf{1 0}$ as a TBS ether $(91 \%)$ followed by the selective removal of the TBDPS group ${ }^{8}$ produced alcohol 12 $(80 \%)$, which was successfully converted to 7 through etherification with tert-butyl bromoacetate followed by basic hydrolysis ( $67 \%$ over 2 steps).

$$
\text { (S)-8 }
$$

Scheme 3. Synthesis of chiral alcohols (R)-8 and (S)-8.

The preparation of chiral allylic alcohols (R)-8 and (S)-8 started from the known enone $\mathbf{1 3}^{9}$ (Scheme 3). Bromination of $\mathbf{1 3}$ followed by elimination of $\mathrm{HBr}$ with $\mathrm{Et}_{3} \mathrm{~N}$ produced $\alpha$-bromo enone 14 (86\%), which was reduced under Luche conditions to give racemic alcohol $8(98 \%){ }^{10}$ After the condensation of 8 with (R)-(-)- $\alpha$-methoxyphenylacetic acid (15), the resulting diastereomeric esters 16 and 17 were separated by preparative HPLC (16: 35\%; 17: 35\%). ${ }^{11}$ The hydrolysis of esters 16 and 17 afforded homochiral alcohols (R)-8 (98\%) and (S)-8 (100\%), ${ }^{12}$ respectively. The absolute configurations of the alcohols were determined by application of the modified Mosher's method on alcohol (S)-8. ${ }^{13}$

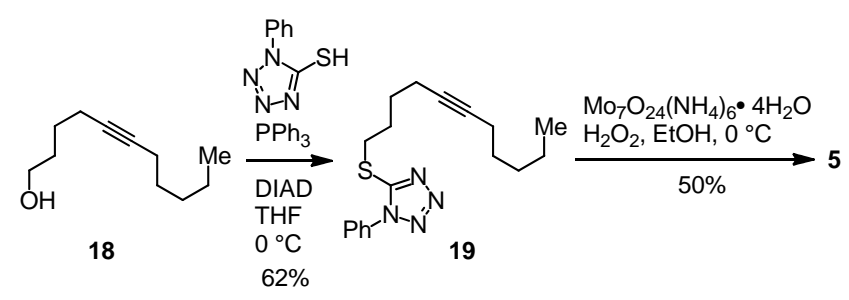

Scheme 4. Preparation of sulfone 5.

Sulfone 5 was prepared from undec-5-yn-1-ol (18) ${ }^{14}$ via a process including Mitsunobu reaction ${ }^{15}$ with 1 -phenyl- $1 H$ tetrazole-5-thiol $(62 \%)$ and oxidation with $\mathrm{H}_{2} \mathrm{O}_{2}$ in the presence of ammonium molybdate hydrate ${ }^{16}(50 \%)$ (Scheme 4).

The stereoselective construction of the C8' stereocenter by Ireland-Claisen rearrangement is shown in Scheme 5. First, glycolic acid 7 was esterified with alcohol $(\boldsymbol{S})-8$ to afford ester (5'S)-6 (97\%). The treatment of (5'S)-6 with NHMDS in the presence of $\mathrm{TMSCl}$ in THF at $-78{ }^{\circ} \mathrm{C}$ produced a ketene silyl acetal intermediate, which was then warmed to $0{ }^{\circ} \mathrm{C}$ to give rearranged product $\left(\mathbf{8}^{\prime} \mathbf{S}\right)-\mathbf{2 0}$ as a single diastereomer. Carboxylic acid (8'S)-20 was condensed with $N, O$-dimethylhydroxylamine to furnish $\mathrm{N}$-methoxy- $\mathrm{N}$-methylamide (8'S)-21 in good yield (80\% over 2 steps). 


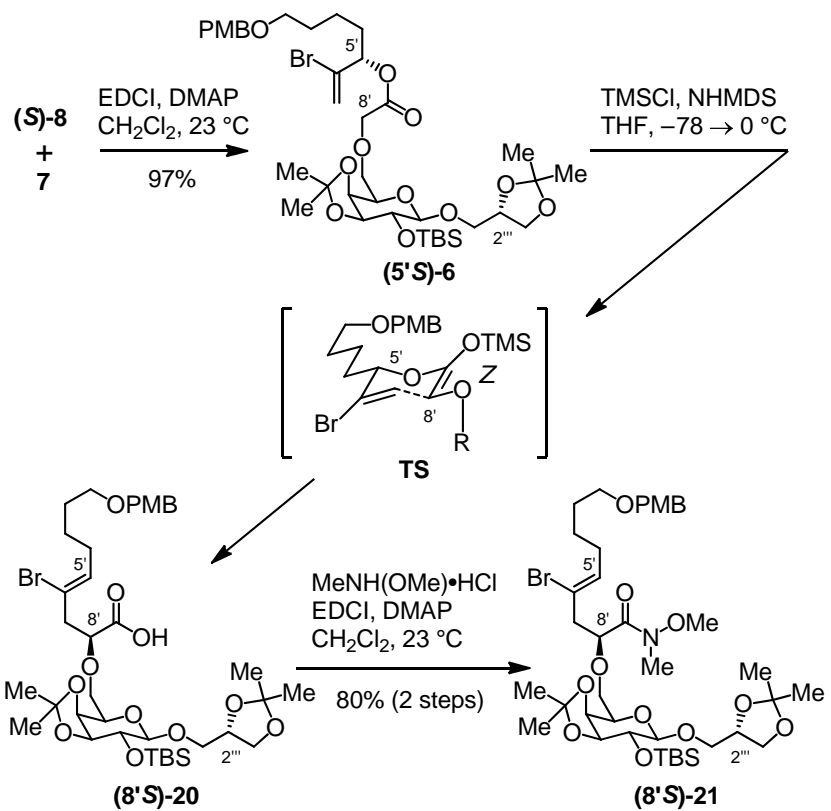

Scheme 5. The Ireland-Claisen rearrangement of ester (5'S)-6.

The absolute stereochemistry at C8' of (8'S)-21 was determined as shown in Scheme 6. First, the bromoalkene of (8'S)-21 was reduced with $\mathrm{Bu}_{3} \mathrm{SnH}$ to alkene 22 (37\%). After the reduction of 22 with $\mathrm{LiAlH}_{4},{ }^{17}$ the resulting aldehyde was reacted with allyl magnesium chloride to give 23 as a 1:1 mixture of diastereomers at C9' (61\%). Diene 23 was then cyclized by ringclosing olefin metathesis with Grubbs' first generation catalyst (24), ${ }^{18}$ and trans-disubstituted cyclohexene 25, of which the trans-relationship between $\mathrm{Ha}$ and $\mathrm{Hb}$ was confirmed by the large $J$ value $(9.3 \mathrm{~Hz})$ between these protons, was obtained in $21 \%$ yield after separation from the corresponding cis-isomer. Alcohol 25 was converted to $(S)$ - and $(R)$-MTPA esters (26). Application of modified Mosher's analysis ${ }^{13}$ to these MTPA esters established the (S)-configuration at $\mathrm{C}^{\prime}$ ', which thus determined the $\left(8^{\prime} S\right)$-configuration in conjunction with the transrelationship between $\mathrm{Ha}$ and $\mathrm{Hb}$.

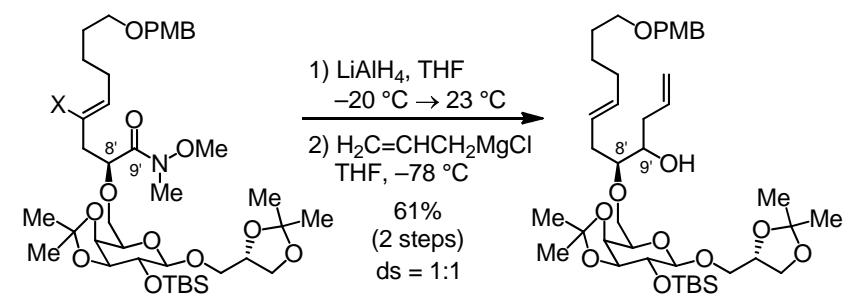

(8'S)-21: $\mathrm{X}=\mathrm{Br}$ ) $\mathrm{Bu}$ SnH, $\mathrm{AIBN}$ 22: $\mathrm{X}=\mathrm{H} 2 \mathrm{PhMe}$, reflux $37 \%$

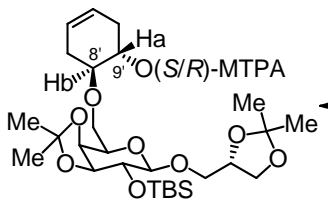

(S/R)-MTPA ester (26)

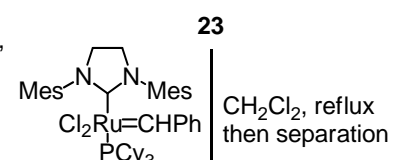$$
24
$$

would be rearranged via a stable chair form transition state (TS in Scheme 5), which would effectively promote the chirality transfer from $\mathrm{C}^{\prime}$ ' to $\mathrm{C} 8$ ' and produce $\left(\mathbf{8}^{\prime} \boldsymbol{S}\right)-20$ exclusively.

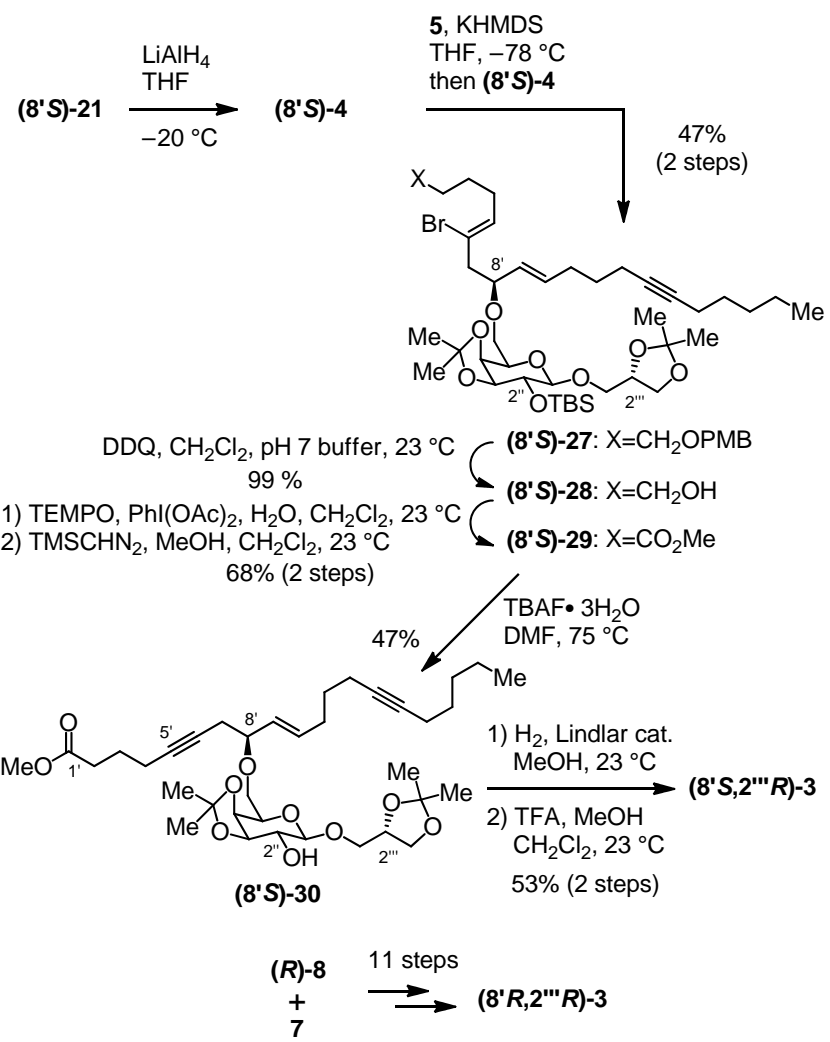

Scheme 7. Completion of the synthesis of $(8 ' S, 2$ '"R)-3 and (8'R,2'"'R)-3.

The completion of the synthesis of model compound (8'S)-3 is illustrated in Scheme 7. Weinreb amide (8'S)-21 was reduced with $\mathrm{LiAlH}_{4}$ to give aldehyde (8'S)-4, which was subjected to Julia-Kocienski olefination with sulfone $\mathbf{5}$ using KHMDS to produce $E$-alkene (8'S)-27 (47\% over 2 steps). The PMB group of (8'S)-27 was removed with DDQ (99\%), and the resulting alcohol (8'S)-28 was converted to methyl ester (8'S)-29 through TEMPO oxidation in the presence of water ${ }^{19}$ followed by treatment with trimethylsilyldiazomethane $\left(68 \%\right.$ over 2 steps). ${ }^{20}$ The bromoalkene group of (8'S)-29 was transformed to an acetylene group [(8'S)-30, 47\%] by treatment with $\mathrm{TBAF} \cdot 3 \mathrm{H}_{2} \mathrm{O}$ in DMF at $75{ }^{\circ} \mathrm{C}$, which also removed the TBS ether at $\mathrm{C} 2 "$, according to Mori's procedure. ${ }^{21}$ Lindlar hydrogenation of $\left(\mathbf{8}^{\prime} \mathbf{S}\right)$ 30 followed by acidic methanolysis of the acetonides produced (8'S,2'"R)-3 (22 $^{22}$ (53\% over 2 steps). Thus, model compound $(8 ' S, 2 ' " R)-3$ was stereoselectively synthesized from 3galactosyl-sn-glycerol derivative $\mathbf{9}$ via a route including chirality transferring Ireland-Claisen rearrangement as a key step. This route was also successfully applied to the synthesis of $\left(8 ' R, 2 '{ }^{\prime} R\right)-3^{23}$ from $(R)-8$ and $7 .^{24}$

With both model compounds (8'S,2'"R)-3 and (8'R,2'" $\boldsymbol{R})-\mathbf{3}$ in hand, we compared the ${ }^{1} \mathrm{H}$ NMR data of the model compounds in $\mathrm{C}_{6} \mathrm{D}_{6} / \mathrm{DMSO}-\mathrm{d}_{6}(25: 2)$ with the reported data of 2 . The deviation of the chemical shifts of the models from those of $\mathbf{2}$ is shown in Fig. 2. While there are large differences in the chemical shifts in the H9'-H16' region between each model and 2 due to the absence of the $\mathrm{C} 16$ fatty acid chain and the oxygen functionalities at $\mathrm{C}^{1} 1^{\prime}$ and $\mathrm{C} 12^{\prime}$ in the model compounds, the chemical shift deviations in other regions of both models are small (within $\pm 0.1 \mathrm{ppm}$ ). The similarity of the ${ }^{1} \mathrm{H}$ NMR spectrum of $\left(8 ' S, 2^{\prime \prime \prime} R\right)-3$ with that of $\mathbf{2}$ is suggested from the fact that the average of the absolute values of the chemical shift deviations of producing (8'S)-20. The initial formation of the ketene silyl acetal would be highly $Z$-selective, and the Z-ketene silyl acetal 
$(8 ' S, 2$ ''R)-3 from 2 (for all protons, except H9'-H16' and hydroxy protons, of the model) is smaller $(0.018 \mathrm{ppm})$ than that of $\left(\mathbf{8}^{\prime} \boldsymbol{R}, \mathbf{2}^{\prime}\right.$ ' $\left.\boldsymbol{R}\right)$-3 $(0.028 \mathrm{ppm})$. However, the $S$-configuration at C8' of 2 cannot be asserted with confidence at this stage due to the presence of significant chemical shift deviations of $\mathrm{H} 4$ " and H6"b of $\left(8^{\prime} S, 2^{\prime \prime \prime R}\right)-3$, as well as the observation that the ${ }^{13} \mathrm{C}$ NMR data of both models significantly deviated from those of 2 (data not shown). Further studies with alternative model compounds are required for the determination of the stereochemistry at $\mathrm{C} 8^{\prime}$ of $2 .^{5}$

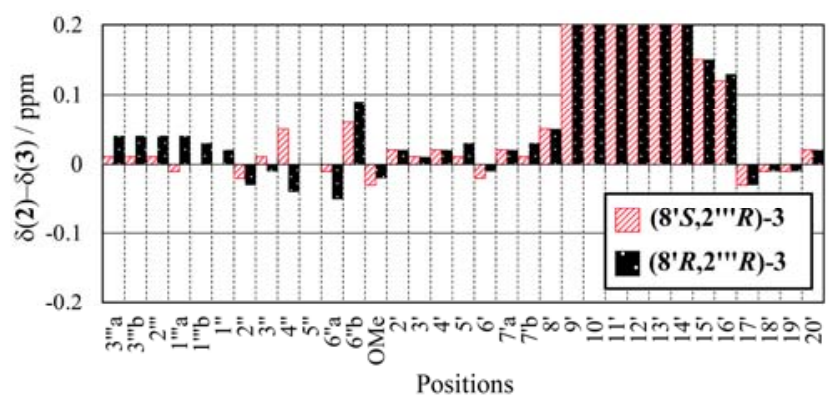

Figure 2. Deviation of ${ }^{1} \mathrm{H}$ NMR chemical shifts of $\mathbf{3}$ from the reported values of 2 . ${ }^{1} \mathrm{H}$ NMR spectra of 3 were measured in 25:2 $\mathrm{C}_{6} \mathrm{D}_{6} / \mathrm{DMSO}-d_{6}$ according to the literature. ${ }^{1}$

In conclusion, a method for the stereoselective construction of the C8'-O-C6" ether of nigricanoside-A (1), an antimitotic natural product from the green alga Avrainvillea nigricans, has been developed based on chirality-transferring Ireland-Claisen rearrangement. The method was successfully applied to the synthesis of simple models [(8'S,2'"R)-3 and $\left.\left(\mathbf{8}^{\prime} \boldsymbol{R}, \mathbf{2}^{\prime} ' \boldsymbol{R}\right)-3\right]$ for the C20 lipid chain/galactosyl glycerol segment of $\mathbf{1}$. Studies on the bioactivity of the model compounds as well as the development of methodologies toward the total synthesis of $\mathbf{1}$ are in progress.

\section{Acknowledgments}

We thank Mr. Kenji Watanabe, Dr. Eri Fukushi, and Mr. Yusuke Takata (GC-MS and NMR Laboratory, Graduate School of Agriculture, Hokkaido University) for the measurements of mass spectra. This work was supported by a Global COE Program (B01: Catalysis as the Basis for Innovation in Materials Science) and Grants-in-Aid for Scientific Research from MEXT, Japan.

\section{References and notes}

1. Williams, D. E.; Sturgeon, C. M.; Roberge, M.; Andersen, R. J. J. Am. Chem. Soc. 2007, 129, 5822.

2. For other synthetic studies on nigricanosides, see: (a) Kurashina, Y.; Kuwahara, S. Biosci. Biotechnol. Biochem. 2012, 76, 605. See, also: (b) Espindola, A. P. D. M.; Crouch, R.; DeBergh, J. R.; Ready, J. M.; MacMillan, J. B. J. Am. Chem. Soc. 2009, 131, 15994. (c) Tortosa, M. Angew. Chem. Int. Ed. 2011, 50, 3950.

3. (a) Ireland, R. E.; Muller, R. H.; Willard, A. K. J. Am. Chem. Soc. 1976, 98, 2868. A review: (b) McFarland, C. M.; McIntosh, M. C. In The Claisen Rearrangement, Hiersemann, M.; Nubbemeyer, U., Eds.; Wiley-VCH: Weinheim, 2007, p 117.

4. For a review: Maréchal, É.; Block, M. A.; Dorne, A.-J.; Douce, R.; Joyard, J. Physiol. Plant. 1997, 100, 65.

5. Models $\left(\mathbf{8}^{\prime} S, 2^{\prime \prime} S\right)-3$ and $\left(\mathbf{8}^{\prime} R, \mathbf{2}^{\prime \prime \prime} S\right)-3$ are also in preparation using the same synthetic method reported in this paper for the comparison of NMR data with $\mathbf{1}$ to determine the configurations at $\mathrm{C} 8^{\prime}$ and $\mathrm{C} 2^{\prime \prime \prime}$ of 1 . The details will be published in due course as a full paper along with the results of bioassays of the four models.

6. Blakemore, P. R.; Cole, W. J.; Kocienski, P. J.; Morley, A. Synlett 1998, 9, 26.
7. Sias, B.; Ferrato, F.; Grandval, P.; Lafont, D.; Boullanger, P.; De Caro, A.; Leboeuf, B.; Veger, R.; Carrière, F. Biochemistry 2004, 43, 10138.

8. Higashibayashi, S.; Shinko, K.; Ishizu, T.; Hashimoto, K.; Shirahama, H.; Nakata, M. Synlett 2000, 11, 1306.

9. Jung, S. H.; Kim, S. H. Bull. Korean Chem. Soc. 2003, 24, 13

10. Gemal, A. L.; Luche, J.-L. J Am. Chem. Soc. 1981, 103, 5454.

11. The separation of $\mathbf{1 6}$ (polar) from $\mathbf{1 7}$ (less polar) was performed by HPLC using a pre-packed column (YMC-Pack SIL-06-5 $\mu \mathrm{m}$, $500 \mathrm{~mm} \times 20 \mathrm{mmID})$ supplied by YMC Co., Ltd. with hexaneethyl acetate eluent $(20 \mathrm{~mL} / \mathrm{min})$.

12. Spectral and physical data of (R)-8: a colorless oil; $[\alpha]_{\mathrm{D}}{ }^{24}-11.2(\mathrm{C}$ $0.14, \mathrm{CHCl}_{3}$ ); IR (neat) $\vee 3414,3034,3000,2939,2862,1612$, $1586,1513,1463,1442,1363,1303,1248,1173,1092,1036,899$, $820,665 \mathrm{~cm}^{-1}$; ${ }^{1} \mathrm{H}$ NMR $\left(300 \mathrm{MHz}, \mathrm{CDCl}_{3}\right) \delta 1.30-1.53(2 \mathrm{H}, \mathrm{m},-$ $\left.\mathrm{C}_{\underline{H}^{-}}\right), 1.53-1.79\left(4 \mathrm{H}, \mathrm{m},-\underline{\mathrm{H}}_{2}-\times 2\right), 1.97(1 \mathrm{H}, \mathrm{d}, J=6.0 \mathrm{~Hz}, \mathrm{OH})$, $3.45\left(2 \mathrm{H}, \mathrm{t}, J=6.4 \mathrm{~Hz},-\mathrm{OC}_{2}-\right), 3.80\left(3 \mathrm{H}, \mathrm{s},-\mathrm{OC} \underline{\mathrm{H}}_{3}\right), 4.08(1 \mathrm{H}, \mathrm{q}$, $J=6.0 \mathrm{~Hz},-\mathrm{CH}(\mathrm{OH})-), 4.42\left(2 \mathrm{H}, \mathrm{s},-\mathrm{OCH}_{2}-\mathrm{Ar}\right), 5.55(1 \mathrm{H}, \mathrm{brd}, J=$ $1.8 \mathrm{~Hz},=\mathrm{CH}-), 5.86(1 \mathrm{H}, \mathrm{brs},=\mathrm{CH}-), 6.88(2 \mathrm{H}, \mathrm{d}, J=8.5 \mathrm{~Hz}$, PMB $), 7.26(2 \mathrm{H}, \mathrm{d}, J=8.5 \mathrm{~Hz}, \mathrm{PMB}) ;{ }^{13} \mathrm{C} \mathrm{NMR}(75 \mathrm{MHz}$, $\left.\mathrm{CDCl}_{3}\right) \delta 21.9\left(\mathrm{CH}_{2}\right), 29.2\left(\mathrm{CH}_{2}\right), 34.8\left(\mathrm{CH}_{2}\right), 55.2\left(\mathrm{CH}_{3}\right), 69.7$ $\left(\mathrm{CH}_{2}\right), 72.4\left(\mathrm{CH}_{2}\right), 75.7\left(\mathrm{CH}_{2}\right), 113.7(\mathrm{CH} \times 2), 116.7\left(\mathrm{CH}_{2}\right), 129.2$ $(\mathrm{CH} \times 2), 130.5$ (C), 137.5 (C), 159.0 (C); EI-HRMS m/z calcd. for $\mathrm{C}_{15} \mathrm{H}_{21} \mathrm{BrO}_{3}\left(\left[\mathrm{M}^{+}\right]\right)$328.0674, found 328.0696. Spectral and physical data of $(S)-8$ : a colorless oil; $[\alpha]_{\mathrm{D}}^{23}+11.1$ (c 0.14 , $\left.\mathrm{CHCl}_{3}\right)$; IR, 1H NMR and 13CNMR spectra are identical with those of $(\boldsymbol{R})-8$; EI-HRMS $\mathrm{m} / \mathrm{z}$ calcd. for $\mathrm{C}_{15} \mathrm{H}_{21} \mathrm{BrO}_{3}\left(\left[\mathrm{M}^{+}\right]\right)$ 328.0674 , found 328.0674 .

13. Ohtani, I.; Kusumi, T.; Kashman, Y.; Kakisawa, H. J. Am. Chem. Soc. 1991, 113, 4092.

14. Evans, R. W.; Sprecher, H. Chem. Phys. Lipids 1985, 38, 327.

15. Mitsunobu, O. Synthesis 1981, 13, 1.

16. Williams, D. R.; Ihle, D. C.; Plummer, S. V. Org. Lett. 2001, 3, 1383.

17. Nahm, S.; Weinreb, S. M. Tetrahedron Lett. 1981, 22, 3815.

18. Schwab, P.; Grubbs, R. H.; Ziller, J. W. J. Am. Chem. Soc. 1996, 118, 100.

19. Pradhan, P. P.; Bobbitt, J. M.; Bailey, W. F. J. Org. Chem. 2009, $74,9524$.

20. Hashimoto, N.; Aoyama, T.; Shioiri, T. Chem. Pharm. Bull. 1981, 29, 1457.

21. Okutani, M.; Mori, Y. J. Org. Chem. 2009, 74, 442.

22. Spectral and physical data of $\left(\mathbf{8}^{\prime} S, \mathbf{2}^{\prime \prime} \boldsymbol{R}\right)-3$ : a pale yellow oil; $[\alpha]_{\mathrm{D}}^{23}-2.2\left(c 0.10, \mathrm{CHCl}_{3}\right)$; IR (neat) $v 3406,2925,2855,1731$ $\mathrm{cm}^{-1}$; ${ }^{1} \mathrm{H}$ NMR (400 MHz, $\mathrm{C}_{6} \mathrm{D}_{6} / \mathrm{DMSO}_{6} \mathrm{~d}_{6}$ [25:2], $\mathrm{C}_{6} \mathrm{HD}_{5}$ as 7.15 ppm) $\delta 0.86\left(3 \mathrm{H}, \mathrm{t}, J=7.0 \mathrm{~Hz}, \mathrm{H} 20^{\prime}\right), 1.30$ (2H, m, H18'), 1.30 (2H, m, H19'), 1.32 (2H, m, H17'), 1.39 (2H, m, H12'), 1.61 (2H, m, H3'), 1.97 (2H, m, H11'), 1.99 (2H, m, H4'), 2.03 (2H, m, H13'), $2.03\left(2 \mathrm{H}, \mathrm{m}, \mathrm{H} 16^{\prime}\right), 2.14\left(2 \mathrm{H}, \mathrm{t}, J=7.6 \mathrm{~Hz}, \mathrm{H} 2{ }^{\prime}\right), 2.30(1 \mathrm{H}, \mathrm{m}$, H7'a), 2.47 (1H, m, H7'b), 3.40 (3H, s, OMe), 3.65 (1H, m, H5"), 3.68 (1H, m, H3"), 3.73 (1H, m, H6"a), 3.75 (1H, m, H8'), 3.87 (2H, m, H3"'), 3.95 (1H, m, H6"b), 3.95 (1H, m, H1"'a), 3.97 (1H, m, H2"), 3.98 (1H, m, H4"), 4.08 (1H, m, H2"'), 4.14 (1H, m, H1"'b), 4.41 (1H, d, $\left.J=7.6 \mathrm{~Hz}, \mathrm{H} 1^{\prime \prime}\right), 5.40(1 \mathrm{H}, \mathrm{m}, \mathrm{H} 5 '), 5.40(1 \mathrm{H}$, m, H9'), $5.40\left(1 \mathrm{H}, \mathrm{m}, \mathrm{H} 14{ }^{\prime}\right), 5.40\left(1 \mathrm{H}, \mathrm{m}, \mathrm{H} 15^{\prime}\right), 5.57(1 \mathrm{H}, \mathrm{m}$, $\left.\mathrm{H}^{\prime} 0^{\prime}\right), 5.61$ (1H, m, H6') [Chemical shifts are shown as exact values derived from $1 \mathrm{D}, \mathrm{COSY}$, HSQC, and $\mathrm{HMBC}$ measurements.]; ${ }^{13} \mathrm{C}$ NMR (100 MHz, $\mathrm{C}_{6} \mathrm{D}_{6} / \mathrm{DMSO}_{6}$ [25:2], $\mathrm{C}_{6} \mathrm{D}_{6}$ as $\left.128.0 \mathrm{ppm}\right) \delta 14.25\left(\mathrm{CH}_{3}, \mathrm{C}_{2}^{\prime} 0^{\prime}\right), 22.87\left(\mathrm{CH}_{2}, \mathrm{C} 19^{\prime}\right), 25.05$ $\left(\mathrm{CH}_{2}, \mathrm{C}^{\prime}\right), 26.99\left(\mathrm{CH}_{2}, \mathrm{C}^{\prime}\right), 27.08\left(\mathrm{CH}_{2}, \mathrm{C} 133^{\prime}\right), 27.51\left(\mathrm{CH}_{2}\right.$, $\left.\mathrm{C} 16^{\prime}\right), 29.62\left(\mathrm{CH}_{2}, \mathrm{C} 12^{\prime}\right), 29.69\left(\mathrm{CH}_{2}, \mathrm{C} 17^{\prime}\right), 31.75\left(\mathrm{CH}_{2}, \mathrm{C} 18^{\prime}\right)$, $32.09\left(\mathrm{CH}_{2}, \mathrm{C} 11^{\prime}\right), 33.39\left(\mathrm{CH}_{2}, \mathrm{C} 2{ }^{\prime}\right), 34.26\left(\mathrm{CH}_{2}, \mathrm{C} 7^{\prime}\right), 51.05\left(\mathrm{CH}_{3}\right.$, $\mathrm{OMe}), 64.06\left(\mathrm{CH}_{2}, \mathrm{C} 3 " '\right), 68.14\left(\mathrm{CH}_{2}, \mathrm{C} 6 "\right), 69.62$ (CH, C4"), 71.64 (CH, C2"'), 71.98 (CH, C2"), $72.39\left(\mathrm{CH}_{2}, \mathrm{C} 1{ }^{\prime \prime}\right), 74.51(\mathrm{CH}$, C3"), 74.78 (CH, C5"), 81.38 (CH, C8'), 105.05 (CH, C1"), 127.19 (CH, C6'), 129.77 (CH, C14'), $130.30(\mathrm{CH}, \mathrm{C} 5 '), 130.40(\mathrm{CH}$, $\left.\mathrm{C}^{\prime} 5^{\prime}\right), 131.33$ (CH, C9'), $133.57\left(\mathrm{CH}, \mathrm{C}^{\prime} 0^{\prime}\right), 173.46$ (C, C1'); FDHRMS calcd for $\mathrm{C}_{30} \mathrm{H}_{52} \mathrm{O}_{10} \mathrm{Na}\left[\mathrm{M}+\mathrm{Na}^{+}\right]$: 595.3458, found: 595.3463.

23. Spectral and physical data of $\left(\mathbf{8}^{\prime} \boldsymbol{R}, \mathbf{2}^{\prime \prime} \boldsymbol{R}\right)-3$ : a pale yellow oil; $[\alpha]_{\mathrm{D}}{ }^{24}+2.8\left(c 0.10, \mathrm{CHCl}_{3}\right)$; IR (neat) $v 3387,2926,2861,1737$ $\mathrm{cm}^{-1} ;{ }^{1} \mathrm{H}$ NMR $\left(400 \mathrm{MHz}, \mathrm{C}_{6} \mathrm{D}_{6} / \mathrm{DMSO}-d_{6}\right.$ [25:2], $\mathrm{C}_{6} \mathrm{HD}_{5}$ as 7.15 ppm) $\delta 0.86\left(3 \mathrm{H}, \mathrm{t}, J=7.0 \mathrm{~Hz}, \mathrm{H} 20^{\prime}\right), 1.30\left(2 \mathrm{H}, \mathrm{m}, \mathrm{H} 18^{\prime}\right), 1.30$ (2H, m, H19'), 1.32 (2H, m, H17'), 1.38 (2H, m, H12'), 1.61 (2H, m, H3'), 1.96 (2H, m, H11'), 1.99 (2H, m, H4'), 2.02 (2H, m, H13'), $2.02\left(2 \mathrm{H}, \mathrm{m}, \mathrm{H} 16^{\prime}\right), 2.14\left(2 \mathrm{H}, J=7.6 \mathrm{~Hz}, \mathrm{H} 2^{\prime}\right), 2.30$ (1H, m, H7'a), 2.45 (1H, m, H7'b), 3.39 ( $3 \mathrm{H}, \mathrm{s}, \mathrm{OMe}), 3.65$ (1H, m, H5"), 3.70 (1H, m, H3"), 3.75 (1H, m, H8'), 3.77 (1H, m, H6"a), 3.84 (2H, m, H3"'), 3.90 (1H, m, H1"'a), 3.92 (1H, m, H6"b), 3.98 (1H, m, H2"), 4.05 (1H, m, H2"'), 4.07 (1H, m, H4"), 4.11 (1H, m, H1"'b), 4.39 $\left(1 \mathrm{H}, \mathrm{d}, J=7.7 \mathrm{~Hz}, \mathrm{H} 1^{\prime}\right), 5.38\left(1 \mathrm{H}, \mathrm{m}, \mathrm{H} 5^{\prime}\right), 5.39$ (1H, m, H9'), $5.40\left(1 \mathrm{H}, \mathrm{m}, \mathrm{H} 14^{\prime}\right), 5.40$ (1H, m, H15'), 5.57 (1H, m, H10'), 5.60 $\left(1 \mathrm{H}, \mathrm{m}, \mathrm{H}^{\prime}\right)$ [Chemical shifts are shown as exact values derived 
from 1D, COSY, HSQC, and HMBC measurements.]; ${ }^{13} \mathrm{C}$ NMR $\left(100 \mathrm{MHz}, \mathrm{C}_{6} \mathrm{D}_{6} / \mathrm{DMSO}-d_{6}[25: 2], \mathrm{C}_{6} \mathrm{D}_{6}\right.$ as $\left.128.0 \mathrm{ppm}\right) \delta 14.25$ $\left(\mathrm{CH}_{3}, \mathrm{C}_{2} \mathrm{O}^{\prime}\right), 22.87\left(\mathrm{CH}_{2}, \mathrm{C} 19^{\prime}\right), 25.05\left(\mathrm{CH}_{2}, \mathrm{C}^{\prime}\right), 26.99\left(\mathrm{CH}_{2}\right.$, $\left.\mathrm{C}^{\prime}\right), 27.06\left(\mathrm{CH}_{2}, \mathrm{C} 13^{\prime}\right), 27.51\left(\mathrm{CH}_{2}, \mathrm{C} 16^{\prime}\right), 29.54\left(\mathrm{CH}_{2}, \mathrm{C} 12^{\prime}\right)$, $29.68\left(\mathrm{CH}_{2}, \mathrm{C} 17^{\prime}\right), 31.75\left(\mathrm{CH}_{2}, \mathrm{C} 18^{\prime}\right), 32.06\left(\mathrm{CH}_{2}, \mathrm{C} 11^{\prime}\right), 33.39$ $\left(\mathrm{CH}_{2}, \mathrm{C}^{\prime}\right), 34.23\left(\mathrm{CH}_{2}, \mathrm{C}^{\prime}\right), 51.04\left(\mathrm{CH}_{3}, \mathrm{OMe}\right), 64.05\left(\mathrm{CH}_{2}\right.$, C3"'), 67.67 ( $\left.\mathrm{CH}_{2}, \mathrm{C} 6 "\right), 69.38$ (CH, C4"), 71.61 (CH, C2"'), 71.99 (CH, C2"), $72.41\left(\mathrm{CH}_{2}, \mathrm{Cl}\right.$ "'), $74.32(\mathrm{CH}, \mathrm{C} 5 "), 74.54$ ( $\left.\mathrm{CH}, \mathrm{C} 3 "\right)$,
$81.26\left(\mathrm{CH}, \mathrm{C}^{\prime}\right), 105.13\left(\mathrm{CH}, \mathrm{Cl}^{\prime \prime}\right), 127.19$ (CH, C6'), 129.74 (CH, C14'), 130.29 (CH, C5'), $130.41\left(\mathrm{CH}, \mathrm{C}^{\prime} 5^{\prime}\right), 131.30(\mathrm{CH}$, $\mathrm{C}^{\prime}$ ), $133.68\left(\mathrm{CH}, \mathrm{C} 10^{\prime}\right), 173.43$ (C, C1'); FD-HRMS calcd for $\mathrm{C}_{30} \mathrm{H}_{52} \mathrm{O}_{10} \mathrm{Na}\left[\mathrm{M}+\mathrm{Na}^{+}\right]: 595.3458$, found: 595.3473

24. The Ireland-Claisen rearrangement of ester (5'R)-6 gave stereoselectively (8' $\mathbf{R})-\mathbf{2 1}$ as an almost single isomer in $67 \%$ yield after amidation. 